\title{
Introduction: Framing Bedil, Arguing the Indo-Persian Self
}

\author{
Sajjad Rizvi \\ University of Exeter, Exeter, UK \\ s.h.rizvi@exeter.ac.uk \\ Prashant Keshavmurthy \\ Institute of Islamic Studies, McGill University, Montreal, Quebec, Canada \\ prashant.keshavmurthy@gmail.com
}

What is the self? How does it emerge? What are its constituents? To what extent are our conceptions of the self, our construction of selfhood and personhood tied to specifically culturally conditioned notions of agency, modernity, literature and politics that arise in Europe? Can there ever be a truly global approach to the history of the self? It is precisely these questions that animate our endeavour in this volume, to draw upon a specific case study within a Persianate context — of Bedil Dihlavī_to inform our globalizing discourse on the self.

There is little doubt that we live in self-obsessed times in which the desire to live authentically, to be concerned with our particular existence, to consider ourselves to be good moral agents, to tell our story and recognize ourselves in other more communally constructed and inclusive stories, seems to be central to live metropolitan lives, perhaps peculiarly in the West. As argued by Charles Guignon and more famously Charles Taylor, the rise of this self from the 18th century is tied to some of the values of the Enlightenment and the bold assertion of the independence of the human self, unfettered by the authorities of God and other political-theological institutions. ${ }^{1}$ From the need to find the authentic self in 'your absolute core', as self-help works will often argue in rather emotivist ways - that deliberately violate the notion of the self that is embedded in a tradition and a community of interpretation as Alasdair MacIntyre would have $i^{2}$ — to the idea of the possession of the self and the

\footnotetext{
1 Charles Taylor, Sources of the Self: The Making of Modern Identity (Cambridge: Cambridge University Press, 1989); Charles Guignon, On Being Authentic (London: Routledge, 2004).

2 Alasdair MacIntyre, After Virtue (London: Duckworth, 1981).
} 
rejection of any other's possession over one's self, the modern worldview of the self that privileges its desires, wants, experiences and futures over that of any other, whether individual or a collectivity; modern identity in that sense is dialogical and conflictual.

Modern selfhood thus is constituted by two elements, the first an introspective turn inward and consequently a need to act in a way that is true to oneself-consistent with an earlier askesis of the self that reflected the intimate link between will and action or the knowledge of the self and the need to act accordingly, but distinct in its diagnosis of that self that is the ground for action. When some individuals and cultures articulate critiques of such a Western model of the individual, they reflect a sense of a loss of tradition, of a notion of a fully rounded self whose embodiment is also an expression of its acculturation and socially embedded reality. The rise of this Enlightenment self is very much the victory of a thorough-going naturalism in which no claims to enchantment or that which is beyond the tangible or material can be countenanced. The liberated self, as Guignon points out, may well lead to new and more confined forms of control—indeed as Foucault showed through his notions of governmentality and the apparatus - that are no less pernicious and reductive than earlier forms of restricting the self through the dictates of heaven or some other external authority. ${ }^{3}$

The story of the rise of the self in western cultures takes on three masks and modes of fashioning. The first concerns the ontology of the self. Is there such a thing as a self that is a ground for experiences, thoughts and the agencies? Is that self some substantive being that emerges as part of a duality that is the human, as famously argued by Descartes and more recently by Galen Strawson? ${ }^{4}$ Or is it a mere first person perspective and a bundle of experiences that seems to link the phenomenal self, as articulated by Parfit, Gallaher and others, to some Buddhist notions of no-self $?^{5}$ Is our self discrete or are our experiences, awareness, consciousness and mental states part of a wider stream in a panpsychist world in which, as it were, other minds do not obtain? ${ }^{6}$

3 Guignon, On Being Authentic, 157-67.

4 Galen Strawson originally in Mental Reality (Cambridge: MIT Press, 1994), and more recently in Selves (Oxford: Oxford University Press, 20o9).

5 Derek Parfit, Reasons and Persons (Oxford: Oxford University Press, 1986); Dan Zahavi, Subjectivity and Selfhood: Investigating the First-Person Perspective (Cambridge: мIт Press, 2005); Mark Siderits et al (eds), Self, No Self? Perspectives from Analytical, Phenomenological \& Indian Traditions (Oxford: Oxford University Press, 2011).

6 David Chalmers, The Conscious Mind (Oxford: Oxford University Press, 1996); Barry Dainton, The Phenomenal Self (Oxford: Oxford University Press, 2008); Philip Goff, Consciousness and Fundamental Reality (Oxford: Oxford University Press, 2017), although he defends a version that is named Russellian monism which one might argue is more a form of quasi-physicalist panpsychism. 
Where does this self come from? Alain de Libera in his recent major study of the emergence of the self in Western philosophy ties its origins to the notion of the persons within the Trinity, especially as enunciated by Augustine and in subsequent commentators. ${ }^{7}$ This, of course, makes this history of the self particular to a Christian (and post-Christian) tradition — just as most other philosophers do for slightly different reasons. For such an eminent medievalist who has engaged with Avicennian and Avveroist ideas on the nature of the human rational soul —one thinks of Avicenna's famous suspended person thought experiment (and one need not even stretch to its determining influence upon Descartes) and Averroes' monopsychism - this myopia is quite astounding. Or perhaps it is the need to pick other types of fights, not least against the thorough anti-humanism of much postwar post-structuralist French thought?8 Richard Sorabji's intellectual history of the self locates its emergence from the older notion of the soul and the life of the soul, its origins, identity and faculties and its afterlife; the Greek origins of the self are thus quite clear in this account although at least he engages with some Buddhist notions of the self and also with Avicenna's famous thought experiment. ${ }^{9}$ Nevertheless, what one notices in the philosophical account of the self in Western philosophy is both at times a universalizing claim about the category of the human as well as a culturally embedded and specific set of intellectual trajectories particular to Europe.

The second mask, that follows from the ontological, is the moral. Once God was displaced and the moral code given by revelation set aside, the main question was how to reconstruct morality in the absence of external authority. The old Euthyphro dilemma of deciding whether the source of value lay in independent human reason or in revelation was decisively answered in favour of the former. Acts could be intrinsically good or bad. While the concern with moral psychology and character persisted, there was a shift to actions as expressions of the self and less concern with the self as such. This shift was

7 Alain de Libera, L'invention du sujet moderne (Paris: Vrin, 2015); idem, Archéologie du sujet, 3 volumes (Paris: Vrin, 2010-2014).

8 On this anti-humanism, see the excellent study of Stefanos Geroulanos, An Atheism that is Not Humanist Emerges in French Thought (Stanford: Stanford University Press, 2010).

9 Richard Sorabji, Self: Ancient and Modern Insights about Individuality, Life, and Death (Oxford: Oxford University Press, 2006), especially 222-229, 278-297. Even on the related idea of human rights — rights that pertain to the category of the human-there is a similar debate that locates its origins either in Christian debates or in the understanding of the Enlightenment's category of the person-for the former, see Samuel Moyn, The Last Utopia: Human Rights in History (Cambridge: The Belknap Press, Harvard, 2010) and for the latter Lynn Hunt, Inventing Human Rights (New York: Norton, 2007). In either case, human rights discourse is given an exclusively European pedigree. 
then tied to the emergence of the liberal, atomistic, Enlightenment self with political values, negative liberty and notions of contractual relationships in inter-subjective public ethics. The cruder version of this moral self was Francis Fukuyama's The End of History and the Last Man published as an opinion piece in 1989 and then as a book, genuflecting to the Hegelian tradition and Kojève. ${ }^{10}$ The liberal self was the perfected self at the culmination of history; liberalism is a set of hard fought values against impositions of external authority and the most perfect form of morality and political theory that the world has known and hence ought to be universalized. This was not an agonistic liberalism that concerned itself with its internal discontents, its history of violence, nor with its proximate others such as Islam. ${ }^{11}$ Nor was it willing to consider non-Hellenic origins for our practices of liberal democracy. Larry Siedentrop's history of the liberal self — the individual — with its hard won values of equality and individual liberty and democracy is concerned with the history of the West, indeed of Christendom, and is conscious of the fact that not only is the West and its individuality a unique historical process but Islam, represented in the hordes invading Europe, represents the very antithesis of the West. ${ }^{12}$ This is the Enlightenment as a Graeco-Christian event, a process that culminates in the liberalism and Protestantism of the present. It could have been called 'How the West was won'. But there is no problematization of the notion of the West. ${ }^{13}$ Andrew Gamble in a recent article argues how the very notion of the West and its values denotes a universalization of neo-liberalism and of a narrow definition of Anglo-American values, policies and institutions. ${ }^{14}$ If this was a truly liberal Western self, it would be more tolerant of dissident selves within the West as well.

10 Francis Fukuyama, 'The End of History?' The National Interest 16 (1989): 3-18; idem, The End of History and the Last Man (New York: Free Press, 1992). Cruder still is Steven Pinker's recent Enlightenment Now: The Case for Science, Reason, Humanism and Progress (New York: Viking, 2018), which has the added advantage of being thin on philosophical and historical expertise and thick on the dismissal of the agonistic and critical nature of the humanities.

11 John Gray, Enlightenment's Wake (London: Routledge, 1995), and Two Faces of Liberalism (Cambridge: Polity Press, 200o); Domenico Losurdo, Liberalism: A Counter-History (London: Verso, 2014); Joseph Massad, Islam in Liberalism (Chicago: University of Chicago Press, 2016).

12 Larry Siedentrop, Inventing the Individual: The Origins of Western Liberalism (London: Penguin, 2015).

13 For this, one might look at Georgios Varouxakis, 'The godfather of occidentality: Auguste Comte and the idea of the West', Modern Intellectual History (2017): 1-31, and Rolf Petri, $A$ Short History of Western Ideology (London: Bloomsbury, 2018).

14 Andrew Gamble, "The Western Ideology", Government and Opposition, Volume 44, Issue 1, 2009, 1-19. 
The third mask is the literary one that concerns the emergence of the self and the individual in European literatures. Jerrold Seigel ties the idea of the self in Western Europe since the seventeenth century to processes of literary narration and philosophical introspection..$^{15}$ As classic 'intellectual history', it takes ideas and expressions seriously and argues for the coherence, consistency and persistence of the self as a narrative. It is therefore not surprising that the most narrated and consciously introspective literary form - the novel—might be tied to the rise of this modern self. This argument is made more categorically by both Harold Bloom and Stephen Greenblatt, the former through the identification of Shakespeare and the early modern period for the invention of the individual (indeed the category of the 'human') and the latter's notion of the revival of classicism and naturalism in the early modern period. ${ }^{16}$ That intellectual shift then bore literary fruit. A feature of that modern literary self is the desire to narrate the nation through the self. The rise of national languages and literatures - as Benedict Anderson argues-is directly connected to the imagined community of the nation and demonstrates not only the construction of European nations and literatures but also those peoples affected by the colonial experience in which nationalism emerged as a set of elite discourses about political identity. ${ }^{17}$ Even there one could point to the secondary and devolved sense of the novel as expression of self in those non-European contexts, and Frederic Jameson famously dismissed most such works as thin allegories of the nation. ${ }^{18}$ Nevertheless, does this mean that we seek the modern non-Western self in these 'national allegories'? Where can we look for global discourses?

The current vogue for the label 'global' requires that we not only provincialize some of these discourses of the rise of the modern self in their European intellectual history but also look for other trajectories of self-narration. It is precisely in this context that we wish to interrogate the notions of the self and indeed the modern that can be applied to a pivotal Persian poet of the late Mughal period, 'Abd al-QQādir Bedil, whose influence on the modern literary

15 Jerrold Siegel, The Idea of the Self: Thought and Experience in Western Europe since the Seventeenth Century (Cambridge: Cambridge University Press, 2005).

16 Harold Bloom, Shakespeare: The Invention of the Human (London: Fourth Estate, 1998), and Stephen Greenblatt, The Swerve: How the Renaissance Began (Oxford: Bodley Head, 2011).

17 Benedict Anderson, Imagined Communities: Reflections on the Origin and Spread of Nationalism (London: Verso, 1983).

18 Frederic Jameson, 'Third-World literature in the ear of multinational capitalism', Social Text 15 (1986): 65-88. For incisive critiques, see Aijaz Ahmad, "Jameson's rhetoric of otherness and the national allegory", Social Text 16 (1987): 3-25. Imre Szeman, in fact, argues that Jameson has been misread—see 'Who's afraid of national allegory?' The South Atlantic Quarterly, 100 (2001): 803-827. 
canon and modalities of literary expression can be gauged through his influence on the literary giants of the modern period such as Ghālib, Iqbāl and others. Can we engage in global intellectual history and find a multi-layered approach to modernities and selfhood beyond the West? In the Persianate context, there are already some important precursors. Mohamad Tavakoli-Targhi has made an argument for Persian modernity and selfhood that is tied to texts but also histories that differ from the standard trajectory of the Greeks to the Christians to the Renaissance to the Enlightenment to the present. ${ }^{19}$ Similarly, more recently both Rajeev Kinra and Sunil Sharma have considered Mughal literary practices in India and their modern turn through the narration and expression of the literary self. ${ }^{20}$ The search for the self in the intersection of the Indian and the Persianate is also timely given the recent interventions of Jonardon Ganeri in Indian philosophy and the centrality of the care of the self and the art of the self in Indian philosophies across the traditional Vedic schools and beyond. ${ }^{21}$ That notion of selfhood was linked to the 'new reason' of the early modern period, a new style and discourse of philosophizing. ${ }^{22}$ It is therefore the coming together of the Persianate and the Indian in the thought of Bedil that demands our attention, his narrating of a self that is at once comfortable with Vedic ideas and epics and also at home with the philosophical thought of Avicenna and the mystical insights of Ibn 'Arabì. But why pick a poet, even one as philosophically astute as Bedil?

The modernisation of poetic practice across Asia and Africa from the early twentieth century onward was its increasingly exclusive identification with lyric understood, as in Europe of the time, as the verbal expression of the inner states of a biographically particular individual. This identification was also a conflation-perhaps confusion — of poetic meter with "dated diction and subject matter". ${ }^{23}$ The ghazal is one of only two pre-modern Persianate poetic forms - the other being the rubāi or quatrain-to have survived this early twentieth century revolution of free verse. It survived (in Persian, Urdu, Turkish, Pashto and other Persianate languages) because certain of its practitioners and readers recognized in its poetics elements of what could

19 Mohamad Tavakoli-Targhi, Refashioning Iran: Orientalism, Occidentalism and Historiography (Basingstoke: Palgrave Macmillan, 2001).

$20 \quad$ Rajeev Kinra, Writing Self, Writing Empire (Oakland: University of California Press, 2015), and Sunil Sharma, Mughal Arcadia (Cambridge: Harvard University Press, 2017).

21 Jonardon Ganeri, The Concealed Art of the Soul (Oxford: Oxford University Press, 2007), and Identity as Reasoned Choice (London: Bloomsbury, 2012).

22 Jonardon Ganeri, The Lost Age of Reason (Oxford: Oxford University Press, 2011).

23 Timothy Steele, Missing Measures:Modern Poetry and the Revolt Against Meter (University of Arkansas Press, 199o), 55 . 
be recombined to meet the requirements of the preeminent modern poetic form-the lyric.

However, it was not the Romantic Wordsworthian model of the lyric that allowed this survival but the modernist one. Modernism, understood here as a set of literary and aesthetic practices that foregrounded their own devices in anti-illusionistic ways, discovered a predecessor in the ghazal. Rather than the ghazal of the earliest phases of Persian literary history, it was the ghazal from the sixteenth to eighteenth centuries that formed an aesthetic resource for Persianate modernism. ${ }^{24}$ This was because the ghazal of this late phase, as practiced by poets who identified with the style they called Speaking Anew (tāza-gūyù, shīva-yi tāza, tarz-itāza, tarz-inow), foregrounded its inherited conventions in just the sort of playful, exploratory ways that modernism did with the many pasts it appropriated.

The ghazals of Sāeb Tabrīzì (d. 1676) and Bedil Dihlavī (d. 1720) were conspicuous models for such modernist appropriation and were considered stylistic thresholds even in the lifetimes of the two poets. Their poetry and that of scores of other poets in this style radicalized the reflexivity of early modern Persian literary culture. That is, it tested and took to new limits the tendency beginning in the early 1500 s to survey and synthesise inherited ghazal conventions in metaphor, syntax and figures of speech. ${ }^{25}$ As the examples below will show, poetry in this style folded language upon itself, seldom allowing realist and indexical modes of reference to the world. For this very reason, the nationalist literary canons of Iran, Afghanistan, Tajikistan, India and Pakistan took shape over the twentieth century by either repudiating Bedil for his stylistic distance from the Romantic lyric or by appropriating him for his Sufi and thus, on this interpretation, non-elite and progressive credentials. Modernism, when it arose in these literary communities, often took the form of iterations of pre-modern non-realist aesthetics. To study selfhood in Bedil today is, in this sense, to study poetry made newly legible by various Asian-African modernisms inspired by it; and to return indirectly to the very question of modernist lyric subjectivity in the postcolonial world.

There is another stake to studying selfhood in Bedil today-that of intellectual history. As his student Ārzū remarked, Bedil's vast and variegated oeuvre was put in the service of a single imperative: Sufism. ${ }^{26}$ Specifically, Bedil be-

24 For a survey of the poetics of the ghazal of this period, see Shamsur Rahman Faruqi, Early Urdu Literary Culture and History (New Delhi: Oxford University Press, 2001), 145-84.

25 Paul E. Losensky, Welcoming Fighani: Imitation and Poetic Individuality in the Safavid-Mughal Ghazal (Costa Mesa: Mazda, 1998).

26 Sirāj al-Dīn Khān Ārzū, Majma al-nafāyis: bakhsh-i mu'ạṣirān (Tehrān: Anjuman-i āsāar-i mafākhir-i farhangī, 1384/2006), 54 . 
longed to one of the many traditions of reading and reformulating Ibn 'Arabī's (d. 1240) theist monism. His oeuvre reveals few philosophical-theological ideas that are original, few that were not already in Ibn 'Arabì or his major glossators. But this is precisely what allows us to assert the autonomy of poetry as a kind of thinking from discursive genres of writing in Islamic intellectual history. Bedil put his innovative poetics in the service, not of new ideas, but of new ways in which to alert his reader to old ideas from Ibn 'Arabì's long reception. In this sense, studying his rhetoric of selfhood presents us with innovations in the ethical practice by which ideas already familiar from Ibn 'Arabī might be recognized and realised.

Finally, a third stake impels our interest in selfhood in Bedil. His oeuvre is culturally bisemic, constituting an acme of around two centuries of efforts in Persian literary culture to think certain Hindu and Islamic traditions of ethical self-transformation together. This is explicit in his masnavis in which he embeds tales from the Yogavāsișțha, a popular Sanskrit philosophical text composed sometime between the $5^{\text {th }}$ and 12 th centuries. By the Mughal period it had become a teaching text for the Advaita Vedānta philosophical tradition and its ninth century abbreviation, Laghuyogavāsișța ("Shorter Yogavāsiștha"), was rendered into Persian multiple times. We know that Bedil drew two of the tales in his earliest masnavì Muhitt-i a zam and several cosmogonic elements and plot devices in his last masnavi Irfän from one of these Persian adaptations that was made in 1656 by the Mughal prince Dārā Shukūh, in both cases extending Dārā's interest in reading this Sanskrit text in ways that were amenable to both Vedantic and Akbarian (i.e. Ibn 'Arabï's) readings. ${ }^{27}$ But implicitly and more challengingly, such a bisemic poetics also characterizes his ghazals. Consider this distich, one of around ten in his ghazal corpus that uses the metaphor of the peacock's egg to convey the emergence of a sensorily rich phenomenal Many from the single and abstract greater reality of the One.

tīghat chih afsūn dāsht kih chun bayża-yi țāvūs
gul mïkunad az khāk-i shahìd-i tu shafaq-hä

A translation conveying only the salient senses of the lexemes might be:

27 'Abd al-Qādir Bedil, Irfān (9-395) and Muhît-i a'zam (704-19) in Kulliyāt-i Bedil: jild-i sevvum (Tehran: Chāpkhānah-yi Payām, 1386/2008). For a study of Bedil's adaptation of tales from the Yogavāsiștha, see Hajnalka Kovacs, "The Tavern of the Manifestation of Realities: the Masnavi Muhît-i a żam by Mirzā 'Abd al-Qādir Bedil (1644-1720)” (University of Chicago: PhD dissertation, 2013), 112-72.

28 'Abd al-Qādir Bedil, Kulliyāt-i Bedil: Jild-i avval (Tehrān: Chāpkhānah-yi Payām, 1386/ 2008), 430. 
What wonders did your sword work that, like the peacock's egg, The horizon's flush rises from your martyr's dust?

A translation attentive to the non-salient senses might go:

What wonders did your sunray work that, like the peacock's egg, Mercy blossoms from your martyr's dust?

But the verbal compound gul kardan also means 'to snuff out', yielding yet another translation:

What wonders did your sword work that, like the peacock's egg, Mercy was snuffed out by your martyr's dust?

Addressing the divine beloved who is by poetic convention cruel to the loverspeaker, the distich invokes the image of a peacock's egg lanced by a sword or a sunray (tigh means both) and leaking a peacock's iridescent colours, here implied in the pluralisation of shafaq which means both "the reddish flush at dawn or dusk" as well as "affection and mercy". The shahid, meaning witness and martyr at once, witnesses God's multifarious world only at his martyrdom. Across his oeuvre, Bedil emphasizes the sensory richness of the phenomenal world as an aspect of its unreality. Here, creation's horizon-flush is also God's love or mercy for His creation. But equally, it is the end of such mercy for birth itself, as Bedil often says elsewhere in his oeuvre, is an affliction; and the beloved's sword was a trimming of creation's candle till it flared into darkness.

The conspicuous images of this distich cite multiple traditions at once: the Neoplatonic Illuminationist metaphysics of light that was appropriated by the Mughals as a political theology; Bhartrihari's (6th century CE) Sanskrit philosophical grammar that famously uses the metaphor of the peacock's egg to account for how the "word, which in itself has no parts and no sequence, unfolds itself so as to give rise to something that appears to have both, just as the vital essence (rasa) of a peacock's egg, which does not possess the variety of colours of a peacock, unfolds itself so as to give rise to a peacock that does"; ${ }^{\prime 2}$ Khāqānì's mention of the golden egg of "dawn's peacock" in one of his qasidahs; and Sāeb's ghazal image of the peacock's bloody tulip-bright birth from a steel egg lanced by the blade-like mountaintop. What distinguishes Bedil's re-use of this compound metaphor from Khāqānī and Sāeb's is the Akbarian

29 Johannes Bronkhorst, “The Peacock's Egg: Bhartṛhari on Language and Reality", Philosophy East and West, 51. 4 (2001): 474-91. 
topos (mażmūn) of phenomenal multiplicity issuing from a single, greater and abstract or transcendent reality - the "dust" of Bedil's distich. That he is consistent in his uses of this compound metaphor for this topos across his ghazals strengthens the probability that he derived this image from a Persian and possibly Vedantic recension, oral or written, of Bhartrihari's vision of unpartitioned language giving rise to a partitioned reality.

These, then, are three sets of reasons for why we should take an interest today in questions of selfhood in Bedil's oeuvre: to revisit the question of nonWestern poetic modernisms by considering their pre-colonial models; to revisit the place of poetry in Islamic intellectual history; and to study the integration into the poetics of a single author of long standing Islamicate-Persianate interest in Sanskrit and other Indic language philosophy. But further, we want to place this interrogation of Bedil into the wider frame of asking the question about the nature of selfhood and alternative trajectories of the modern self in non-European contexts that may contribute to a more nuanced and rich understanding of the history of selfhood, subjectivity, and modern poetics in intellectual history. 